\title{
Quality evaluation of slaughterhouse waste compost $^{1}$
}

\author{
Rebeka Sanabria ${ }^{2}$,Abner A. Rodríguez-Carias ${ }^{3}$, David \\ Sotomayor-Ramirez ${ }^{4}$ and Elide Valencia ${ }^{4}$
}

J. Agric. Univ. P.R. 93(3-4):223-238 (2009)

\begin{abstract}
This study evaluated physical and chemical characteristics and the stability and maturity of slaughterhouse waste (SHW) composted with fresh (FYT) or with semicomposted yard trimmings (SCYT). Also evaluated was the agronomic response of the gramineous forage Brachiaria brizantha cv. Mulato to the application of 0 and $400 \mathrm{~kg} \mathrm{~N} / \mathrm{ha}$ as SHW compost. The treatments evaluated were composts containing none, single, or double layers of SHW with FYT or with SCYT as bulking agents. Also evaluated were three commercial composts made from vegetable residues, yard trimmings, goat manure and alluvial residues (CC1); these same materials minus alluvial residues (CC2); and sewage sludge and wood chips (CC3). Among treatments, FYT-single layer SHW compost had the highest concentrations $(P<0.05)$ of organic matter (OM) $(687 \mathrm{~g} / \mathrm{kg})$ and carbon (C) $(382 \mathrm{~g} / \mathrm{kg}) ; C C 1$ and CC2 presented very high inorganic matter concentration $(779$ and $743 \mathrm{~g} / \mathrm{kg}$, respectively); C:N ratio was highest for SCYT-single layer SHW (15.61). The mineral profile, cation exchange capacity, particle density, and electrical conductivity of the experimental treatments were within accepted limit values usable for compost. No significant differences were observed for relative germination of seeds exposed to the composts, whereas root elongation and germination index differed $(P<0.05)$ among treatments but not in a systematic manner. After six weeks of growth of the forage grass fertilized with the composts, chlorophyll concentration, $\mathrm{N}(\%)$, and biomass (g DM/pot) exhibited low values in all treatments. The composts evaluated were mature and stable and constituted potentially useful soil amendments; however, as indicated by the agronomic performance, compost alone, even when applied at equivalent $\mathrm{N}$ rate of $400 \mathrm{~kg} / \mathrm{ha}$, cannot provide the optimum quantities of nutrients that cultivar Mulato needs for initial rapid development.
\end{abstract}

Key words: Compost, slaughterhouse wastes, agronomic performance

\section{RESUMEN}

Evaluación de la calidad de composta de residuos de mataderos comerciales

En este estudio se evaluaron las características químicas y físicas y la madurez y estabilidad de composta producida con residuos de mataderos comerciales (RM) y residuos de jardinería frescos (RJF) o semicompostados (RJSC). El valor agronómico de las compostas se determinó al fertilizar la

${ }^{1}$ Manuscript submitted to Editorial Board 19 September 2007.

${ }^{2}$ Ex graduate student Department of Animal Industry.

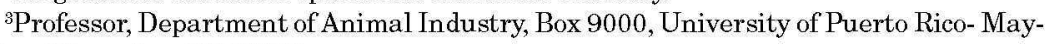
agüez, Mayagüez, PR 00680.

${ }^{4}$ Professor, Department of Crops and Agroenvironmental Sciences. 
gramínea Brachiaria brizantha cv. Mulato con dosis equivalentes a 0 y $400 \mathrm{~kg}$ N/ha. Los tratamientos experimentales fueron RJF y RJSC utilizados como agentes absorbentes y compostados entre capas sencillas, dobles, 0 sin RM. Se evaluaron también tres compostas comerciales producidas con residuos vegetales, RJF y excreta de caprinos, con o sin arena de río (CC1 y $\mathrm{CC} 2$, respectivamente) y otra producida con cieno sanitario y madera (CC3). Entre tratamientos, la composta de RJF con capas sencillas de RM tuvo la mayor $(P<0.05)$ concentración de materia orgánica (MO) $(687 \mathrm{~g} / \mathrm{kg})$ y carbono (C) (382 g/kg); CC1 y CC2 tuvieron una alta concentración de materia inorgánica (MI) $(779$ y $743 \mathrm{~g} / \mathrm{kg}$, respectivamente), mientras que la composta RJSC con capas sencillas de RM tuvo la razón C: $N$ más alta (15.61). En todos los tratamientos, el perfil de minerales, la capacidad de intercambio catiónico, la densidad de partículas y la conductividad eléctrica estuvieron dentro de los valores aceptables utilizados para composta. No se observaron diferencias significativas en el porcentaje de germinación relativa, mientras que el largo de la raíz y el índice de germinación varió $(P<0.05)$ entre tratamientos pero no de manera sistemática. A las seis semanas de fertilizar la gramínea con las compostas, la concentración de clorofila, el porcentaje de nitrógeno y la biomasa (MS/tiesto) mostraron valores bajos en todos los tratamientos. Todas las compostas evaluadas se categorizaron como maduras y estables y constituyen un material potencial para enmendar suelos. Sin embargo, de acuerdo con su rendimiento agronómico, las compostas individuales, aun aplicadas a razón de $\mathbf{4 0 0} \mathrm{kg} / \mathrm{ha}$, no proveen las cantidades óptimas de nutrientes que el cultivar Mulato necesita para su crecimiento.

Palabras clave: Composta, residuos de mataderos, valor agronómico

\section{INTRODUCTION}

Previous experiments have shown that it is possible to compost slaughterhouse waste (SHW) using fresh yard trimmings (FYT) and semicomposted yard trimmings (SCYT) as bulking agents (Sanabria, 2006). However, no attempts have been made to evaluate the quality of the final product as organic fertilizer. Compost quality is defined by its stability and maturity. Mature and stable compost releases nutrients to the soil gradually during the crop growth cycle. In contrast, immature and unstable compost may develop anaerobic conditions and thus may generate phytotoxic compounds (e.g., volatile organic acids) which may cause difficulties during storage and subsequent use. Stability refers to the organic matter's degree of decomposition. Maturity refers to the organo-chemical state related to the degree of decomposition of phytotoxic compounds produced in the active phases of composting. Maturity indicates the presence or absence of these compounds in stable to very stable compost (Thompson, 2002; Wu et al., 2000). Presently, there is neither an accepted methodology nor a specific parameter to determine the maturity and stability of the compost. However, a combination of different physical, chemical, and biological criteria can be used to assess the compost's quality, such as $\mathrm{pH}$, organic matter $(\mathrm{OM})$, total $\mathrm{N}, \mathrm{N}-\mathrm{NH}_{4}, \mathrm{~N}_{-} \mathrm{NO}_{3}$, $\mathrm{C}: \mathrm{N}$ ratio, macro and micro mineral analyses, cation exchange capacity (CEC), particle density, electrical conductivity, and germination index. 
The objective of this study was to evaluate the physical and chemical properties of composts made from no SHW, or single, or double layers of SHW with FYT and SCYT as the bulking agents, and then to assess the stability and maturity of the resulting product. The agronomic response of a forage grass fertilized with the composts was also determined. The experimental composts were also compared with three commercial composts in terms of stability, maturity and agronomic response.

\section{MATERIALS AND METHODS}

\section{Stability and maturity tests}

Composts made of SHW and FYT or SCYT (two-month-old) were obtained from previous experiments and compared, in terms of stability and maturity, with three commercial composts. Two of the commercial composts were made from vegetable residues, yard trimmings and goat manure, with or without alluvial residues ( $\mathrm{CC} 1$ and $\mathrm{CC} 2$, respectively). These were obtained from the composting facilities at the Alzamora Farm, University of Puerto Rico, Mayagüez Campus. The third commercial compost (CC3) was made from sewage sludge and wood chips and was obtained from a commercial composting facility. To determine compost stability and maturity, we analyzed samples from each compost for dry matter, OM, inorganic matter (IM), N and C content, and $\mathrm{C}: \mathrm{N}$ ratio by using standard procedures (AOAC, 1991). The $\mathrm{pH}$ was measured in a mixture of deionized water with compost at a rate of $2: 1$ (v/w). Soluble salt content was measured by the electrical conductivity test described by Standard Methods for the Evaluation of Water and Wastewater (SMEWW, 1999). Cation exchange capacity was measured by the method of ammonium saturation (Thompson et al., 2002; Black et al., 1965). The concentrations of $\mathrm{N}-\mathrm{NH}_{4}$ and $\mathrm{N}-\mathrm{NO}_{3}$ were determined from the saturated paste extraction solution (Thompson et al., 2002; Keeny and Nelson, 1982). Particle density was measured by using a modification of the method of Blake and Hartge (1986), in which ethanol instead of water was used as the solvent. Samples from each compost were digested in a microwave system $(10 \mathrm{~min})$. Extracts were used to determine concentration of the mineral elements ( $\mathrm{P}, \mathrm{K}, \mathrm{Ca}, \mathrm{Mg}, \mathrm{Fe}$, $\mathrm{Mn}, \mathrm{Zn}, \mathrm{Cu}, \mathrm{B}, \mathrm{Mo}, \mathrm{Cd}$, and $\mathrm{Na}$ ) in a commercial laboratory (Soil, Plant and Water Laboratory, University of Georgia) $)^{5}$.

\footnotetext{
${ }^{5}$ Company and trade names in this publication are used only to provide specific information. Mention of a company or trade name does not constitute a warranty of equipment or materials by the Agricultural Experiment Station of the University of Puerto Rico, nor is this mention a statement of preference.
} 
Data obtained from chemical and physical assays were analyzed according to a completely randomized design with nine treatments (FCYT and SCYT both with no, single or double layers of SHW; CC1, $\mathrm{CC} 2$, and $\mathrm{CC} 3$, respectively) and three-time replication by using the GLM procedure of SAS (Steel and Torrie, 1990). Means of treatments showing significant differences in the ANOVA were ranked according to the Tukey multiple comparison test option at a probability level of 0.05 unless otherwise noted (SAS, 1990).

Maturity of the experimental and commercial composts was evaluated by using biological assays. Compost extracts (2:1 water to compost, v/w) were filtered through Whatman No.1 paper and then placed in petri dishes with five corn (Zea mays) seeds. Petri dishes containing the extracts and seeds were placed in a dark germination incubator for seven days at $27^{\circ} \mathrm{C}$. Distilled water was used as a control. Germination percentage and root elongation relative to those of the control were determined at the end of the incubation period. The germination index was the product of the germination percentage of each treatment relative to that obtained with water (Das et al., 2003; Thompson et al., 2002).

Data from biological assays were statistically analyzed according to a completely randomized design with 10 treatments (the nine treatments mentioned above plus the treatment with water) and five replications by using the GLM procedure of SAS (Steel and Torrie, 1990). Means of treatments showing significant differences in the ANOVA were ranked by using the LSD procedure.

\section{Agronomic evaluation}

Experimental and commercial composts were evaluated as to their ability to provide nutrients to crops (agronomic value). A pot experiment was established to evaluate the nine compost treatments as fertilizer; Brachiaria brizanta cv. Mulato was the test crop. Fifty pots, 24-cm diameter, were used for this evaluation. A control treatment without fertilizer was also included. The soil series used was Fraternidad (fine, smectitic, isohypothermic Typic Hapluderts). Composts were added at two nutrient application rates ( 0 and $400 \mathrm{~kg} \mathrm{~N} / \mathrm{ha}$ ) and were evaluated after a six-week period of vegetative growth of $\mathrm{Bra}$ chiaria brizanta $\mathrm{cv}$. Mulato. Composts were applied in the upper $2 \mathrm{~cm}$ of soil in the pot and blended uniformly. Grass seeds were germinated and seedlings transplanted to the pots when they reached $10-\mathrm{cm}$ height.

Forty-two days after transplanting, total biomass, leaf color intensity, and $\mathrm{N}$ concentration data were obtained. Biomass was determined 
as the weight of dry vegetative material ( $\mathrm{g} / \mathrm{pot}$ ). Leaf color was estimated by an index related to chlorophyll concentration using the $\mathrm{Mi}$ nolta SPAD-502 Chlorophyll Meter (Spectrum Technologies, Inc, Minolta Co., LTD, Japan). Five leaves per pot per treatment were selected to measure chlorophyll intensity. Three measurements were taken from the middle of each leaf and averaged to obtain a final value per leaf. Nitrogen concentration was measured by distillation following the micro-Kjeldahl digest (AOAC, 1991).

Data were analyzed according to a completely randomized design with 10 treatments and five replications by using the GLM procedure of SAS (Steel and Torrie, 1990). Means of treatment showing significant variation in the ANOVA were separated by using the LSD procedure.

\section{RESULTS AND DISCUSSION}

\section{Stability and maturity tests}

The $\mathrm{pH}$ and chemical composition of the experimental and commercial composts differed among treatments (Table 1 ). The $\mathrm{pH}$ values ranged from acid to neutral. Commercial composts (CC3 and $\mathrm{CC} 1)$ presented significantly higher $(\mathrm{P}<0.05) \mathrm{pH}$ values than those of the experimental composts. The highest $\mathrm{pH}$ value was found in CC3 (7.05). However, none of the $\mathrm{pH}$ values observed fell outside the range considered appropriate for stable compost. Dry matter content was highest in the $\mathrm{CC} 2$ and $\mathrm{CC} 3$ treatments. Organic matter content in CC3 was similar to that of the treatments containing SCYT, but lower than in those with FYT. Among the experimental composts, the three containing FYT had significantly higher $(\mathrm{P}<$ $0.05) \mathrm{OM}$ (663 to $687 \mathrm{~g} / \mathrm{kg}$ ) and C (368 to $382 \mathrm{~g} / \mathrm{kg}$ ) concentrations than the SCYT composts. The commercial composts CC1 and CC2 presented markedly higher $(\mathrm{P}<0.05)$ IM concentration $(779$ and 743 $\mathrm{g} / \mathrm{kg}$, respectively). Treatments of SHW with FYT had higher $(\mathrm{P}<$ $0.05) \mathrm{N}$ concentration than those with SCYT and commercial composts; CC1 and CC2 presented lower $(\mathrm{P}<0.05) \mathrm{N}$ content than experimental composts with SCYT, and were also inferior to CC3. Carbon to nitrogen ratio ranged from 10.99 to 15.01 , being higher $(\mathrm{P}<$ 0.05) in treatments SCYT-single SHW and CC3 than in FYT-double SHW and CC2.

Previous reports are in agreement with these results in terms of compost chemical composition. Madrid et al. (2000) evaluated compost elaborated with different combinations of coffee husks, guinea grass stems, fruit and vegetable wastes, and rabbit manure. The $\mathrm{pH}$ values 


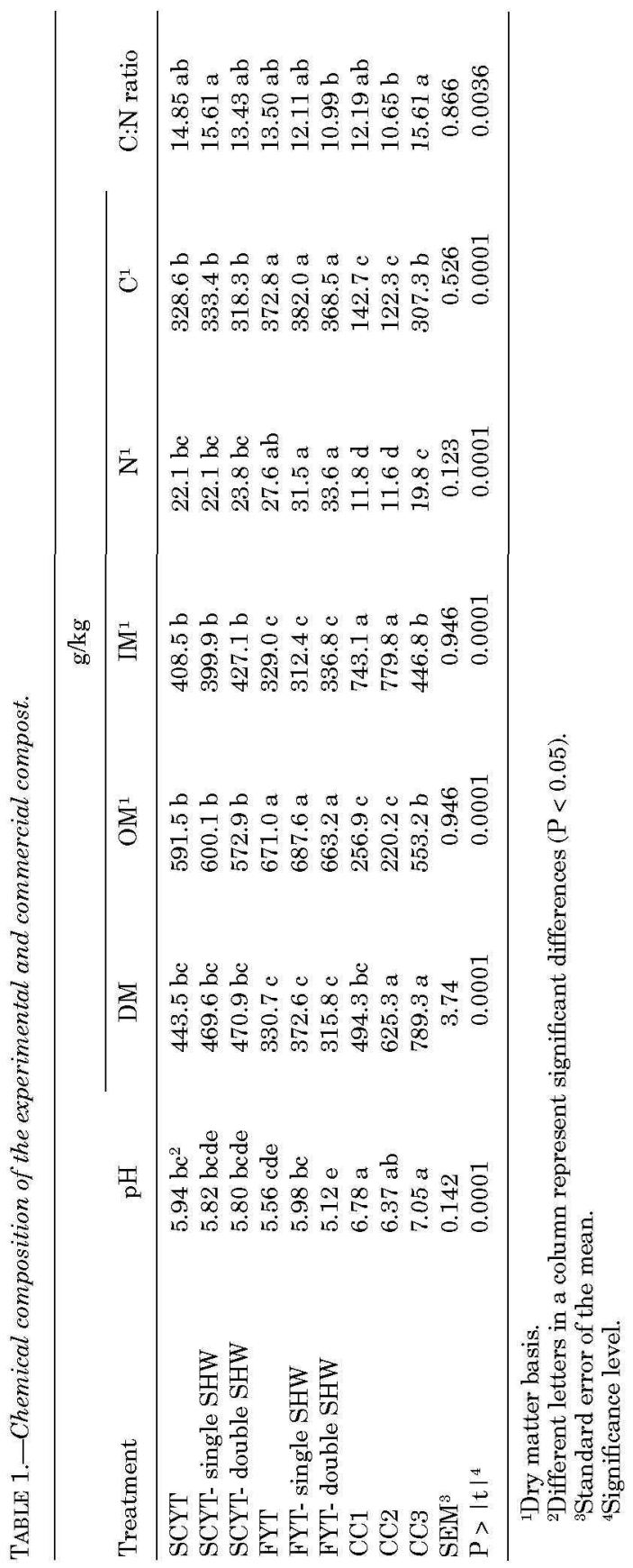


varied from 6.9 to 7.3, and total Kjeldahl $\mathrm{N}$ and organic carbon concentrations ranged from 12.5 to $23.3 \mathrm{~g} / \mathrm{kg}$ and from 152.4 to $251.1 \mathrm{~g} / \mathrm{kg}$, respectively. Values for C:N ratio (11 to 19) and electrical conductivity (4.06 to $5.89 \mathrm{dS} / \mathrm{m}$ ) did not differ significantly among treatments. Standford et al. (2000) evaluated the feasibility of year-round composting of lamb and mature sheep mortalities and determined the value of these composts as fertilizer. Finished compost made of both lamb and sheep had a $7.1 \mathrm{pH}$ value. The chemical analysis of lamb compost resulted in $473 \mathrm{~g} / \mathrm{kg}$ of moisture, $231 \mathrm{~g} / \mathrm{kg}$ of C, $18 \mathrm{~g} / \mathrm{kg}$ of N, 12.7 in C:N ratio, and $12.3 \mathrm{dS} / \mathrm{m}$ in electrical conductivity. Corresponding figures for the sheep compost were $502 \mathrm{~g} / \mathrm{kg}, 283 \mathrm{~g} / \mathrm{kg}, 23 \mathrm{~g} / \mathrm{kg}, 12.2$, and 14.2 $\mathrm{dS} / \mathrm{m}$.

Compost is a source of nutrients for plant growth. Evaluating the quantities of nutrients present in the compost may help determine whether a given compost meets the fertilizer requirements for crop growth. Because of the decomposition that organic wastes undergo in the composting process, there is a limited quantity of macro- and micronutrients in the finished product.

The Cation Exchange Capacity (CEC) value indicates the capacity of compost or mineral and organic soils to hold exchangeable cations to counterbalance the fixed negative charges present in the material (Thompson, 2002). These characteristics influence nutrient availability and retention (Havlin et al., 2005). Harada and Inoko (1980, cited by de Guardia et al., 1998) reported that CEC values greater than 100 meq/ $100 \mathrm{~g}$ OM for animal wastes constitute a stability indicator. Table 2 shows the CEC values of the composts under study. Composts of the SCYT and FYT treatments with all combinations of SHW had statistically similar CEC. Treatments with SCYT also yielded CEC values similar to those of the commercial composts, but FYT composted alone or in combination with a single layer of SHW had higher $(\mathrm{P}<0.05) \mathrm{CEC}$ than commercial composts. In related experiments, Bernal et al. (1998) presented similar CEC values $(124.4 \mathrm{meq} / \mathbf{1 0 0 \mathrm { g }}$ ) for compost made of sewage sludge and cotton waste, whereas García and Valencia (2004) found low CEC values ( $46.3 \mathrm{meq} / 100 \mathrm{~g}$ ) for poultry litter compost.

Plants absorb $\mathrm{N}$ as both $\mathrm{N}-\mathrm{NH}_{4}{ }^{+}$and $\mathrm{N}_{-} \mathrm{NO}_{3}$. For a compost to be stable and mature, these two forms of $\mathrm{N}$ must be present in an adequate proportion. In the present study, $\mathrm{N}_{-} \mathrm{NH}_{4}{ }^{+}$values were higher $(\mathrm{P}<$ 0.05 ) than those of $\mathrm{N}^{-\mathrm{NO}_{3}}{ }^{-}$except for $\mathrm{FYT}$ composts with no layer or double layers of SHW, and CC2 (Table 2). Of all the treatments, CC3 exhibited by far the highest $\mathrm{N}-\mathrm{NH}_{4}{ }^{+}$value $(366.82 \mu \mathrm{g} / \mathrm{ml})$. Nitrate concentration showed statistically similar values among all composts, although the numerical values ranged from 6.11 to $23.44 \mathrm{\mu g} / \mathrm{ml}$ in FYTsingle SHW and SCYT treatments, respectively. Bernal et al. (1998) re- 
TABLE 2.-Chemical and physical properties of experimental and commercial composts.

\begin{tabular}{|c|c|c|c|c|c|c|c|c|c|c|c|}
\hline \multirow[b]{2}{*}{ Parameter $^{1}$} & \multicolumn{11}{|c|}{ Treatments } \\
\hline & SCYT & $\begin{array}{l}\text { SCYT- } \\
\text { single } \\
\text { SHW }\end{array}$ & $\begin{array}{l}\text { SCYT- } \\
\text { double } \\
\text { SHW }\end{array}$ & FYT & $\begin{array}{l}\text { FYT- } \\
\text { single } \\
\text { SHW }\end{array}$ & $\begin{array}{l}\text { FYT- } \\
\text { double } \\
\text { SHW }\end{array}$ & $\mathrm{CC} 1$ & $\mathrm{CC} 2$ & CC3 & $\mathrm{SEM}^{2}$ & $P>|t|^{3}$ \\
\hline CEC (meq/100 g) & $90.36 \mathrm{abc}^{4}$ & $107.40 \mathrm{abc}$ & $108.06 \mathrm{abc}$ & $134.18 \mathrm{a}$ & $123.87 \mathrm{a}$ & $109.12 \mathrm{ab}$ & $64.74 \mathrm{bc}$ & $55.42 \mathrm{c}$ & $56.40 \mathrm{bc}$ & 10.94 & 0.0005 \\
\hline $\mathrm{N}-\mathrm{NH}_{4}(\mu \mathrm{g} / \mathrm{ml})$ & $99.86 \mathrm{bc}$ & $78.71 \mathrm{bc}$ & $195.13 \mathrm{~b}$ & $6.49 \mathrm{c}$ & $7.13 \mathrm{c}$ & $5.09 \mathrm{c}$ & $15.28 \mathrm{bc}$ & $6.62 \mathrm{bc}$ & $366.82 \mathrm{a}$ & 33.9 & 0.0001 \\
\hline $\mathrm{N}-\mathrm{NO}_{3}(\mu \mathrm{g} / \mathrm{ml})$ & 23.44 & 14.01 & 7.39 & 8.92 & 6.11 & 17.58 & 19.11 & 6.62 & 17.07 & 6.773 & 0.4024 \\
\hline $\mathrm{PD}\left(\mathrm{g} / \mathrm{cm}^{3}\right)$ & $1.43 \mathrm{c}$ & $1.30 \mathrm{c}$ & $1.71 \mathrm{bc}$ & $2.64 \mathrm{abc}$ & $2.37 \mathrm{bc}$ & $3.49 \mathrm{ab}$ & $3.94 \mathrm{a}$ & $1.81 \mathrm{bc}$ & $2.04 \mathrm{bc}$ & 0.246 & 0.0001 \\
\hline $\mathrm{EC}(\mathrm{dS} / \mathrm{m})$ & $1.37 \mathrm{~b}$ & $1.32 \mathrm{bc}$ & $1.09 \mathrm{e}$ & $1.30 \mathrm{bcd}$ & $1.34 \mathrm{~b}$ & $1.31 \mathrm{bc}$ & $1.22 \mathrm{~cd}$ & $1.20 \mathrm{~d}$ & $1.62 \mathrm{a}$ & 0.0208 & 0.0001 \\
\hline
\end{tabular}

${ }^{1} \mathrm{CEC}=$ Cation exchange capacity; $\mathrm{N}_{-} \mathrm{NH}_{4}=$ Ammonium nitrogen; $\mathrm{N}-\mathrm{NO}_{3}=$ Nitrate nitrogen; $\mathrm{PD}=$ Particle density.

${ }^{2}$ Standard error of the mean.

${ }^{3}$ Significance level.

${ }^{4}$ Different letters in a row represent significant differences. 


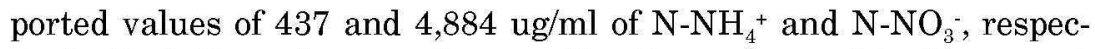
tively, the latter value greatly exceeding those observed in the present study. Other important criteria in the evaluation of compost quality are particle density and salinity. In this experiment, there were significant differences in particle density among treatments (Table 2). The trend was toward higher particle density with FYT than with SCYT, but the difference was significant only for FYT-double SHW over SCYT and SCYT-single SHW; CC1 exceeded all the other composts except FYTdouble SHW in particle density. Salinity in compost, measured as electrical conductivity, showed a high value $(\mathrm{P}<0.05)$ for $\mathrm{CC} 3$ along with certain other significant differences; however, no tendency was evident of the effect of SHW level of FYT vs. SCYT on EC in this experiment. Woods End Research Laboratory (2005) presents standards for the evaluation of salinity in compost testing. This laboratory classifies the salinity concentration $(\mathrm{dS} / \mathrm{m})$ as very low ( $<1.0)$, medium low (1 to 2$)$, medium ( 2 to 5 ), medium high ( 5 to 10 ), and very high ( $>10)$. According to these standards, compost salinity was low for all the present treatments. Ionic components contributing most to salinity are sodium, potassium, chloride, nitrate, sulfate, ammonium, and volatile organic acids (Woods End Research Laboratory, 2005).

In this experiment, mineral analyses of the composts showed a great deal of variability (Tables 3 and 4). Phosphorus values were highest $(\mathrm{P}<0.05)$ for CC3 $(19,028 \mu \mathrm{g} / \mathrm{ml})$, followed by those of CC2 $(7,017$ $\mu \mathrm{g} / \mathrm{ml}$ ) and then those of FYT with both additions of SHW. Potassium content ranged erratically among treatments, from 1,300 to $6,700 \mu \mathrm{g} /$ $\mathrm{ml}$. Magnesium and $\mathrm{Pb}$ concentrations exhibited numerical, but not statistical, differences among composts. Aluminum, $\mathrm{Cr}, \mathrm{Cu}, \mathrm{Na}, \mathrm{Ni}, \mathrm{S}$, and $\mathrm{Zn}$ concentrations were statistically similar for all the SCYT and FYT composts, but there were some differences between these values and those of the commercial products. The highest values of all of these elements were found in CC3; however, the lowest silicon concentration $(392.05 \mu \mathrm{g} / \mathrm{ml})$ was found in CC3. The commercial composts, especially $\mathrm{CC} 2$, tended to have higher Mn values than the experimental composts. The $\mathrm{Ca}$ values were also highest $(\mathrm{P}<0.05)$ for $\mathrm{CC} 3$, whereas among the experimental composts, those with FYT tended to have higher $\mathrm{Ca}$ values than those with SCYT. Finally, the concentration of B was lower $(\mathrm{P}<0.05)$ for SCYT with double layers of SHW than for all of the other treatments. In general, CC3 was outstanding in its high content of several nutrients and for some nutrients either two or all three of the commercial composts showed numerically higher values than those of the experimental composts.

Environmental regulatory agencies in several countries have established standards for maximum concentration of heavy metals in com- 
TABLE 3.-Mineral analysis of experimental and commercial composts.

\begin{tabular}{lccccccccc}
\hline & \multicolumn{7}{c}{ Treatment } \\
\cline { 2 - 10 } $\begin{array}{c}\text { Parameter } \\
(\mu \mathrm{\mu g} / \mathrm{ml})\end{array}$ & SCYT & $\begin{array}{c}\text { SCYT- single } \\
\text { SHW }\end{array}$ & $\begin{array}{c}\text { SCYT- double } \\
\text { SHW }\end{array}$ & FYT & $\begin{array}{c}\text { FYT- single } \\
\text { SHW }\end{array}$ & $\begin{array}{c}\text { FYT- double } \\
\text { SHW }\end{array}$ & CC1 & CC2 & CC3 \\
\hline $\mathrm{Al}$ & $1,539.8 \mathrm{~b}^{1}$ & $1,702.5 \mathrm{~b}$ & $1,745.8 \mathrm{~b}$ & $1,325.2 \mathrm{~b}$ & $1,053.3 \mathrm{~b}$ & $1,388.1 \mathrm{~b}$ & $2,510.1 \mathrm{~b}$ & $5,812.8 \mathrm{~b}$ & $29,219.5 \mathrm{a}$ \\
$\mathrm{B}$ & $5.7 \mathrm{bcd}$ & $7.2 \mathrm{abcd}$ & $2.3 \mathrm{e}$ & $12.2 \mathrm{ab}$ & $12.0 \mathrm{ab}$ & $11.2 \mathrm{abc}$ & $9.3 \mathrm{abc}$ & $6.1 \mathrm{bcd}$ & $15.9 \mathrm{a}$ \\
$\mathrm{Ca}$ & $18,780.6 \mathrm{c}$ & $18,889.2 \mathrm{c}$ & $18,452.6 \mathrm{c}$ & $25,252.6 \mathrm{~b}$ & $25,602.6 \mathrm{~b}$ & $23,622.6 \mathrm{~b}$ & $23,209.2 \mathrm{~b}$ & $19,559.2 \mathrm{bc}$ & $40,962.6 \mathrm{a}$ \\
$\mathrm{Cr}$ & $9.3 \mathrm{~b}$ & $13.3 \mathrm{~b}$ & $11.8 \mathrm{~b}$ & $10.1 \mathrm{~b}$ & $6.0 \mathrm{~b}$ & $5.8 \mathrm{~b}$ & $10.6 \mathrm{~b}$ & $23.3 \mathrm{~b}$ & $58.6 \mathrm{a}$ \\
$\mathrm{Cu}$ & $35.6 \mathrm{~b}$ & $42.1 \mathrm{~b}$ & $34.2 \mathrm{~b}$ & $29.7 \mathrm{~b}$ & $44.2 \mathrm{~b}$ & $31.8 \mathrm{~b}$ & $48.0 \mathrm{~b}$ & $59.3 \mathrm{~b}$ & $598.7 \mathrm{a}$ \\
$\mathrm{K}$ & $3,250.3 \mathrm{abc}$ & $6,716.0 \mathrm{a}$ & $1,309.4 \mathrm{c}$ & $3,228.0 \mathrm{abc}$ & $2,831.7 \mathrm{abc}$ & $1,336.7 \mathrm{c}$ & $5,982.0 \mathrm{ab}$ & $3,673.3 \mathrm{abc}$ & $2,122.0 \mathrm{bc}$ \\
$\mathrm{Mg}$ & $5,177.4$ & $5,640.8$ & $3,922.8$ & $8,469.8$ & $8,316.1$ & $6,952.8$ & $5,242.1$ & $8,904.8$ & $3,263.4$ \\
$\mathrm{Mn}$ & 311.7 & 327.5 & 332.7 & 226.8 & 247.4 & 286.0 & 502.8 & 899.5 & 422.9 \\
$\mathrm{Na}$ & $371.6 \mathrm{~b}$ & $536.9 \mathrm{~b}$ & $201.1 \mathrm{~b}$ & $259.2 \mathrm{~b}$ & $373.3 \mathrm{~b}$ & $320.3 \mathrm{~b}$ & $284.5 \mathrm{~b}$ & $1,019.7 \mathrm{a}$ & $1,119.7 \mathrm{a}$ \\
$\mathrm{Ni}$ & $17.2 \mathrm{~b}$ & $14.8 \mathrm{~b}$ & $18.0 \mathrm{~b}$ & $20.5 \mathrm{~b}$ & $18.4 \mathrm{~b}$ & $11.3 \mathrm{~b}$ & $31.8 \mathrm{ab}$ & $31.5 \mathrm{ab}$ & $58.1 \mathrm{a}$ \\
$\mathrm{P}$ & $2,996.4 \mathrm{~d}$ & $3,079.1 \mathrm{~d}$ & $2,181.4 \mathrm{~d}$ & $3,533.1 \mathrm{~cd}$ & $6,009.7 \mathrm{bc}$ & $6,094.4 \mathrm{bc}$ & $2,765.1 \mathrm{~d}$ & $7,017.1 \mathrm{~b}$ & $19,028.4 \mathrm{a}$ \\
$\mathrm{Pb}$ & 19.9 & 22.2 & 13.2 & 1.7 & 3.2 & 6.9 & 4.9 & 35.2 \\
$\mathrm{~S}$ & $1,406.3 \mathrm{~b}$ & $1,681.0 \mathrm{~b}$ & $2,372.0 \mathrm{~b}$ & $2,831.7 \mathrm{~b}$ & $2,648.0 \mathrm{~b}$ & $2,778.0 \mathrm{~b}$ & $1,403.7 \mathrm{~b}$ & $2,805.4 \mathrm{~b}$ & $11,670.7 \mathrm{a}$ \\
$\mathrm{Si}$ & $1,664.9 \mathrm{ab}$ & $1,571.3 \mathrm{ab}$ & $1,452.3 \mathrm{ab}$ & $1,195.8 \mathrm{ab}$ & $1,143.2 \mathrm{~b}$ & $1,535.6 \mathrm{ab}$ & $2,108.9 \mathrm{a}$ & $1,846.9 \mathrm{ab}$ & $392.1 \mathrm{c}$ \\
$\mathrm{Zn}$ & $211.8 \mathrm{~b}$ & $287.0 \mathrm{~b}$ & $324.6 \mathrm{~b}$ & $403.4 \mathrm{~b}$ & $286.4 \mathrm{~b}$ & $255.5 \mathrm{~b}$ & $178.6 \mathrm{~b}$ & $252.1 \mathrm{~b}$ & $904.9 \mathrm{a}$ \\
\hline
\end{tabular}

*Means in rows with unlike letters differ $(\mathrm{P}<0.05)$. 
TABLE 4.-Standard error and significance levels of variation among treatments in mineral concentration.

\begin{tabular}{lrc}
\hline Parameter & SEM $^{1}$ & $\mathrm{P}>|\mathrm{t}|^{2}$ \\
\hline $\mathrm{Al}$ & 995.33 & 0.0001 \\
$\mathrm{~B}$ & 1.17 & 0.0001 \\
$\mathrm{Ca}$ & $1,064.28$ & 0.0001 \\
$\mathrm{Cr}$ & 6.09 & 0.0003 \\
$\mathrm{Cu}$ & 12.697 & 0.0001 \\
$\mathrm{~K}$ & 822.57 & 0.0037 \\
$\mathrm{Mg}$ & $1,242.85$ & 0.0481 \\
$\mathrm{Mn}$ & 26.109 & 0.0001 \\
$\mathrm{Na}$ & 90.51 & 0.0001 \\
$\mathrm{Ni}$ & 6.32 & 0.0022 \\
$\mathrm{P}$ & 488.92 & 0.0001 \\
$\mathrm{~Pb}$ & 12.597 & 0.4609 \\
$\mathrm{~S}$ & 265.04 & 0.0001 \\
$\mathrm{Si}$ & 132.8 & 0.0001 \\
$\mathrm{Zn}$ & 62.41 & 0.0001 \\
\hline
\end{tabular}

1Standard error of the mean.

${ }^{2}$ Significance level.

posts. The United States Environmental Protection Agency (EPA) limits $\mathrm{Cr}, \mathrm{Cu}, \mathrm{Pb}, \mathrm{Ni}$, and $\mathrm{Zn}$ to 1,$200 ; 1,500 ; 300 ; 420$; and 2,800 $\mathrm{mg} / \mathrm{kg}$, respectively. The Canadian government, under the Canadian Environmental Protection Act, limits concentrations of these five elements, in the same order, more restrictively to $210 ; 128 ; 83 ; 32$; and $315 \mathrm{mg} / \mathrm{kg}$ (Epstein, 1997). The experimental composts in the present study comply with those requirements. Cummings et al. (1993) reported mineral concentration data for composted poultry carcasses in Alabama. Compared with the experimental composts in the present study, these researchers produced material with higher $\mathrm{Cu}, \mathrm{Mn}, \mathrm{Cr}, \mathrm{Pb}, \mathrm{B}$ and $\mathrm{Zn}$ contents $(615 ; 556 ; 57 ; 30 ; 38$; and $499 \mathrm{mg} / \mathrm{kg}$, respectively).

As for relative germination of corn seeds exposed to the composts, no significant differences $(\mathrm{P}>0.05)$ among treatments were observed (Table 5). Although relative root elongation $(>79 \%)$ and germination index $(>87 \%)$ showed significant variation among treatments, no clear response to this treatment factor is discernible. These overall results indicate that the experimental composts were very mature and thus had a low probability of containing phytotoxic compounds that could affect plant germination and growth. Das et al. (2003) evaluated the stability and maturity of food waste compost including synthetic and natural bulking agents. In their study the germination index for all treatments exceeded $70 \%$, a percentage which they considered indicative of stable compost. 
TABLE 5.-Germination index, germination percentage and root length of corn seeds exposed to the experimental and commercial composts

\begin{tabular}{lccc}
\hline Treatments & $\begin{array}{c}\text { Relative } \\
\text { Germination }\end{array}$ & $\begin{array}{c}\text { Relative Root Length } \\
(\mathrm{mm})\end{array}$ & $\begin{array}{c}\text { Germination } \\
\text { index }\end{array}$ \\
\hline SCYT & 100.00 & $79.36 \mathrm{c}^{1}$ & $87.32 \mathrm{c}$ \\
SCYT- single SHW & 108.96 & $114.32 \mathrm{ab}$ & $127.25 \mathrm{ab}$ \\
SCYT- double SHW & 104.48 & $86.52 \mathrm{bc}$ & $91.76 \mathrm{bc}$ \\
FYT & 108.96 & $129.63 \mathrm{a}$ & $144.80 \mathrm{a}$ \\
FYT- single SHW & 111.94 & $124.96 \mathrm{a}$ & $139.88 \mathrm{a}$ \\
FYT- double SHW & 111.94 & $118.32 \mathrm{a}$ & $132.46 \mathrm{a}$ \\
CC1 & 105.54 & $124.82 \mathrm{a}$ & $136.47 \mathrm{a}$ \\
CC2 & 104.48 & $109.98 \mathrm{abc}$ & $121.87 \mathrm{abc}$ \\
CC3 & 104.48 & $120.64 \mathrm{a}$ & $132.21 \mathrm{a}$ \\
Water & 99.15 & $100.02 \mathrm{abc}$ & $109.65 \mathrm{abc}$ \\
SEM & 4.90 & 11.42 & 13.08 \\
P $<\mid \mathrm{t}^{3}$ & 0.6103 & 0.0251 & 0.0202 \\
\hline
\end{tabular}

${ }^{1}$ Means in columns with unlike letters differ $(P<0.05)$.

${ }^{2}$ Standard error of the mean.

${ }^{3}$ Significance level.

\section{Agronomic value}

The agronomic value of the composts was judged by growth of the tropical grass Brachiaria brizantha cv. Mulato. After six weeks of growth, all nine composts (experimental and commercial) showed low fertilizer potential as evidenced by chlorophyll intensity, $\mathrm{N}$ concentration, and biomass production values of the grass (Table 6 ). Chlorophyll intensity value, expressed as SPAD units, was highest $(\mathrm{P}<0.05)$ for the SCYT with double layers of SHW but this value was statistically similar to those of FYT with single or double layers of SHW, and to those of CC1 and CC3.

Nitrogen percentage in the grass was highest $(\mathrm{P}<0.05)$ for the FYT with single or double layer of SHW and SCYT with single layer SHW treatments. In this experiment, a correlation of zero $\left(r^{2}=0\right)$ was found between chlorophyll intensity and nitrogen percentage. It had been expected that as chlorophyll intensity values increased nitrogen percentage would follow the same trend. A possible explanation for this unexpected result is that $\mathrm{N}$ was not the only nutrient limiting the plant growth. As for biomass production, $\mathrm{CC} 3$ application resulted in a markedly higher biomass value ( $4.01 \mathrm{~g} \mathrm{DM} /$ pot) than those of the other composts evaluated, which gave statistically similar weights of biomass (Figure 1). These results differ from the findings of García-Pizarro and Valencia (2004) in their study on the effect of poultry litter compost on the growth of Brachiaria brizantha cv. Mulato, a study in which they 
TABLE 6.-Agronomic evaluations of the experimental and commercial composts used as a growing media for Brachiaria brizantha.

\begin{tabular}{|c|c|c|c|c|c|c|c|c|c|c|c|c|}
\hline \multirow[b]{2}{*}{ Parameter } & \multicolumn{12}{|c|}{ Treatment } \\
\hline & SCYT & $\begin{array}{l}\text { SCYT- } \\
\text { single } \\
\text { SHW }\end{array}$ & $\begin{array}{l}\text { SCYT- } \\
\text { double } \\
\text { SHW }\end{array}$ & FYT & $\begin{array}{l}\text { FYT- } \\
\text { single } \\
\text { SHW }\end{array}$ & $\begin{array}{l}\text { FYT- } \\
\text { double } \\
\text { SHW }\end{array}$ & CC1 & $\mathrm{CC}_{2}$ & CC3 & Water & SEM $^{2}$ & $P<|t|^{3}$ \\
\hline $\begin{array}{l}\text { Chlorophyll } \\
\text { (SPAD units) }\end{array}$ & $18.42 b c^{1}$ & $19.11 \mathrm{bc}$ & $21.74 \mathrm{a}$ & $17.33 \mathrm{c}$ & $19.77 \mathrm{abc}$ & $20.13 \mathrm{abc}$ & $20.85 \mathrm{ab}$ & $17.36 \mathrm{c}$ & $20.70 \mathrm{ab}$ & $18.52 \mathrm{ab}$ & 0.568 & 0.0001 \\
\hline $\mathrm{N}(\%)$ & $0.73 \mathrm{~b}$ & $0.91 \mathrm{a}$ & $0.74 \mathrm{~b}$ & $0.82 \mathrm{~b}$ & $0.94 \mathrm{a}$ & $0.92 \mathrm{a}$ & $0.78 \mathrm{~b}$ & $0.80 \mathrm{~b}$ & $0.80 \mathrm{~b}$ & $0.73 \mathrm{~b}$ & 0.0538 & 0.0563 \\
\hline $\begin{array}{l}\text { Biomass } \\
\text { (g DM/pot) }\end{array}$ & $2.00 \mathrm{~b}$ & $2.10 \mathrm{~b}$ & $1.95 \mathrm{~b}$ & $1.40 \mathrm{~b}$ & $1.78 \mathrm{~b}$ & $1.28 \mathrm{~b}$ & $1.70 \mathrm{~b}$ & $1.28 \mathrm{~b}$ & $4.01 \mathrm{a}$ & $1.29 \mathrm{~b}$ & 0.1781 & 0.0001 \\
\hline
\end{tabular}

${ }^{1}$ Means in columns with unlike letters differ $(\mathrm{P}<0.05)$.

${ }^{2}$ Standard error of the mean.

${ }^{3}$ Significance level. 


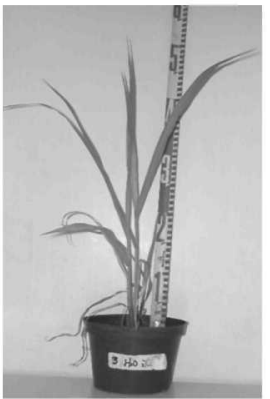

WATER

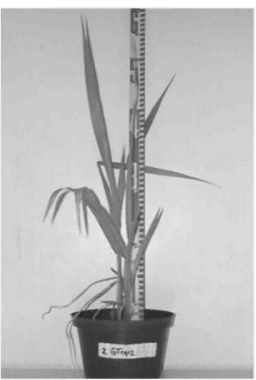

5

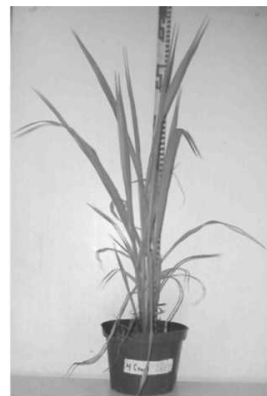

1

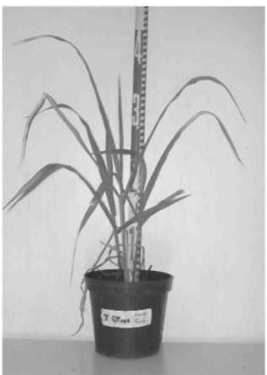

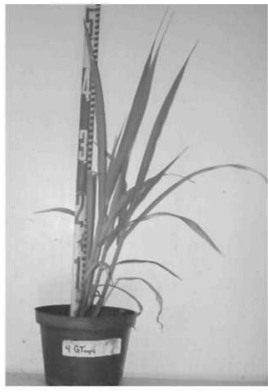

2

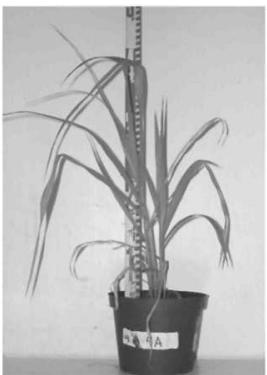

7

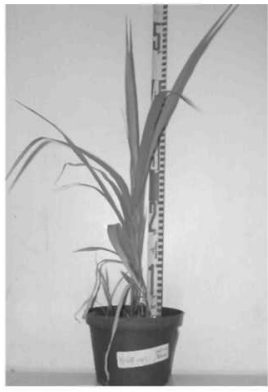

3

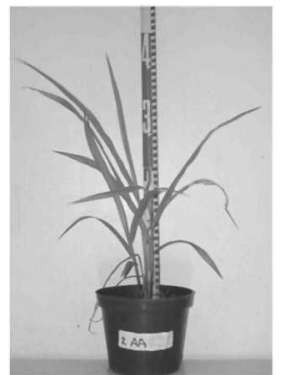

8

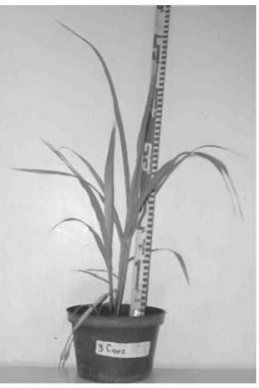

4

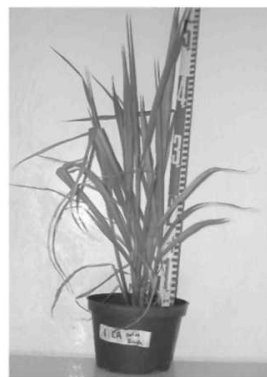

9

FIGURE 1. Brachiaria brizantha six weeks after the application of $400 \mathrm{~kg}$ N/ha

*1 = Semicomposted yard trimmings alone (SCYT); 2 = SCYT and single layer of SHW;3 = SCYT and double layer of SHW; $4=$ fresh yard trimmings alone (FYT); $5=$ FYT and single layer of SHW; $6=$ FYT and double layer of SHW; $7=$ Commercial Compost $1 ; 8=$ Commercial Compost 2;9= Commercial Compost 3. 
evaluated compost inclusion rates of $0,16,31$, and $62 \mathrm{~kg} \mathrm{~N} / \mathrm{ha}$ at three harvesting intervals $(30,60$, and $90 \mathrm{~d})$. In that experiment, plants receiving applications of $62 \mathrm{~kg} \mathrm{~N} / \mathrm{ha}$ from poultry litter compost, and harvested at $90 \mathrm{~d}$, exhibited the highest biomass yields (31, 56, and $81 \mathrm{~g}$ at first, second, and third harvest, respectively). Tissue of plants treated with $62 \mathrm{~kg} \mathrm{~N} / \mathrm{ha}$ had the highest $\mathrm{N}$ concentration (1.46\%), surpassing that observed in the present study.

Stratton and Recheigl (1998) evaluated municipal solid waste compost, yard waste compost and food-plus-yard waste compost applications to rye grass (Lolium multiflorum L.). The inclusion rates of 168 , 336 , and $672 \mathrm{~kg} \mathrm{~N} / \mathrm{ha}$ were chosen by estimating that half of the total $\mathrm{N}$ in the compost might be available in the first growing season. In that experiment, different from the present study and the study of GarcíaPizarro and Valencia (2004), P and K were supplemented in amounts to meet the plant's requirements. Those researchers found that supplemental $\mathrm{N}$ was needed, in addition to each of the composts tested, to achieve establishment of an acceptable stand. However, over the twoyear experimental period, amendments of compost doubled the yields of rye grass over that of unamended plots grown with chemical fertilizers alone.

\section{CONCLUSIONS}

The physical and chemical evaluation of composts of SCYT or FYT with and without SHW showed these products to be stable and mature, comparable to several commercial composts also tested. Both the experimental and commercial composts exhibited an adequate chemical composition and germination index. However, the commercial composts tended to have higher contents of several mineral elements and a lower cation exchange capacity. As the agronomic performance tests showed, these experimental composts would have to be combined with other nutrient sources (i.e., inorganic fertilizers) in order to provide the optimum quantities of nutrients needed by cultivar Mulato during the initial 42 days of growth.

\section{LITERATURE CITED}

AOAC. Official Methods of Analysis, 1990. Association of Official Analytical Chemists. Washington, D.C.

Bernal, M. P., J. Cegara, A. Roig, M. A. Sánchez-Monedero and C. Paredes, 1998. Composting of organic wastes as a strategy for producing high quality organic fertilizers. 8th International Conference on Management Strategies for Organic Waste Use in Agriculture. Rennes, France, 26-29 May 1998. 
Black, C. A., D. D. Evans, J. L. White, L. E. Ensminger and F. E. Clark, 1965. Methods of Soil Analysis Part 2: Chemical and Microbiological Properties. American Society of Agronomy, Madison, Wisconsin.

Blake, G. R. and K. H. Hartge, 1986. Methods of Soil Analysis, Part 1. Physical and mineralogical methods- Agronomy monograph no. 9.

Cummings, C. G., C. W. Wood and D. P. Delaney, 1993. Co-composted poultry mortalities and poultry litter: composition and potential value as fertilizer. J. Sustainable Agric. 4:7-19.

Das, K. C., E. W. Tollner and M. A. Eitman, 2003. Comparison of synthetic and natural bulking agents in food waste composting. Compost Sci. Utilization 11:27-35.

De Guardia, A. D. Rogeau, F. Begnaud and S. Quinio, 1998. Characterization of green wastes' transformations occurring while composting. 8th International Conference on Management Strategies for Organic Wastes Use in Agriculture. Rennes, France, 26-29 May 1998.

Epstein, E., 1997. The Science of Composting. CRC Press LLC, Boca Ratón, Florida. 487 pp.

García-Pizarro, E. and E. Valencia, 2004. Viability of poultry litter compost on growth of Brachiaria brizantha cv Mulato and pollutant effects in the soil. Proceedings Undergraduate Research Program, Department of Animal Industry, University of Puerto Rico Mayagüez. 1:8-15.

Havlin, J. L., S. L. Tisdale, J. D. Beaton and W. L. Nelson, 2005. Soil Fertility and Fertilizers: An Introduction to Nutrient Management. 7th Ed. Pearson Education, Inc,, Upper Saddle River, New Jersey.

Keeny, D. R. and D. W. Nelson, 1982. Nitrogen-Inorganic Forms. Methods of Soil Analysis Part 2-Chemical and microbiological properties. 2nd Ed. American Society of Agronomy, Madison, Wisconsin.

Madrid, C., V. Quevedo and E. Andrade, 2000. Estudio de la biotransformación aeróbica de los desechos lignocelulósicos pergamino de café (Coffea arabica L.) y tallos de pasto guinea (Panicum maximum). Rev. Fac. Agron. 17:505-517.

Sanabria, R., 2006. Composting as an alternative method to dispose of slaughterhouse wastes in Puerto Rico. Thesis M.S., University of Puerto Rico, Mayagüez Campus.

SAS/STAT, 1990. SAS User's Guide (Version 6). SAS Inst., Inc., Cary, NC.

SMEWW, 1999. Standard Methods for the Evaluation of Water and Wastewater. Method 2510. 20th Ed American Public Health Association, American Water Works Association and Water Environment Federation.

Standford, K., F. J. Larney, A. F. Olson, L. J. Yanke and R. H. McKenzie, 2000. Composting as a means of disposal of sheep mortalities. Compost Sci. Utilization 8:135-146.

Steel, R. G. D. and J. H. Torrie, 1990. Principles and Procedures of Statistics: A Biometrical Approach. 2nd Ed. McGraw Hill, New York, NY.

Stratton, M. L. and J. Recheigl, 1998. Compost application to ryegrass. Composting in the Southeast. Proceedings of the 1998 Conference. September 9-11, Athens, Georgia.

Thompson, W. H., P. B. Leege, P. Milner and M. E. Watson, 2002. Test methods for the examination of composting and compost. U.S. Composting Council Online. http:// www.tmecc.org/tmece

Woods End Research Laboratory, 2005. Interpretation of waste and compost tests. $J$. Woods End Res. Lab. 2:1-6.

Wu, L., L. Q. Ma and G. A. Martínez, 2000. Comparison of methods for evaluating stability and maturity of biosolids compost. J. Environ. Qual. 29:424-429. 